\title{
DUKUNGAN SOSIAL DAN TINGKAT STRES ORANG TUA YANG MEMILIKI ANAK RETARDASI MENTAL
}

\author{
Rada Tri Rosi Kurnia ${ }^{1}$, Asri Mutiara Putri ${ }^{2}$, Dita Fitriani² \\ 1Program Studi Pendidikan Dokter Universitas Malahayati Bandar Lampung, \\ email:radatrirosikurnia.97@gmail.com \\ 2Program Studi Psikologi Universitas Malahayati Bandar Lampung, email: asri@malahayati.ac.id \\ 3Program Studi Pendidikan Dokter Universitas Malahayati Bandar Lampung, email:
}

\section{ABSTRACT: SOCIAL SUPPORT AND STRESS LEVEL AMONG PARENTS OF MENTALLY RETARDED CHILDREN}

Parents of children with mental retaradation face challenges placing them at risk for high levels of stress. Social support might decrease the negative impact of stress. The purpose of this study was to analyze the correlation between social support and the stress level among parents of children with mental retaradation. This study was a survey analytical study with cross-sectional design. The sample included 122 parents of mental retaradation children in disabled school at Bandarlampung. Social support in parents was measured through social support scale and stress levels was measured through Perceived Stress Scale 10. Rank Spearman correlation was used to analyze the collected data. The result of this study found that there is significant correlation between social support and stress levels on parents of mental retaradation children $(r=-0.989, p=0.000<0.005)$. Parents that received high level of social support has low level of stress, and vice versa. The result of this study shows the importance of social support in lowering stress level of the parents.

\section{Keywords: Parents, Mental Retaradation, Stress level, social Support, Disabled School}

Orang tua dari anak retardasi mental menghadapi tantangan yang menempatkan mereka pada risiko stres tingkat tinggi. Dukungan sosial dapat menurunkan dampak negatif dari stres. Penelitian ini dilakukan untuk mengetahui hubungan antara dukungan sosial dengan tingkat stres orang tua dari anak retardasi mental. Jenis penelitian ini adalah penelitian survei analitik dengan rancangan cross-sectional. Sampel dalam penelitian ini sebanyak 122 orang. Dukungan sosial pada orang tua diukur dengan skala dukungan sosial dan tingkat stres diukur dengan skala Perceived Stress Scale 10. Teknik analisis data yang digunakan untuk menguji hipotesis yaitu uji korelasi Rank Sperman. Hasil penelitian ini menunjukkan terdapat hubungan yang signifikan antara dukungan sosial dengan tingkat stres pada orang tua dari anak retardasi mental $(r=-0.989, p=0.000<0.005)$. Orang tua yang memperoleh dukungan sosial tinggi memiliki tingak stress yang rendah, dan sebaliknya. Hasil penelitian ini menunjukkan pentingnya dukungan sosial dalam menurunkanstress pengasuhan yang dirasakan orang tua

Kata kunci : Orang Tua, Retardasi Mental, Tingkat Stres, Dukungan Sosial, SLB

\section{PENDAHULUAN}

Retardasi mental didefinisikan sebagai

kondisi fungsi intelektual umum individu yang

sangat dibawah rata-rata sehingga

menyebabkan atau disertai gangguan prilaku

adaptif, yang bermanifestasi selama periode perkembangan (Sadock \& Sadock, 2010). Kondisi ini biasa muncul sebelum usia 18 tahun. Retardasi mental bukanlah suatu penyakit, melainkan suatu proses patologis di otak yang ditandai adanya keterbatasan fungsi adaptif dan intelektual (Sadock \& Sadock, 2010). 


\section{DUKUNGAN SOSIAL DAN TINGKAT STRES PADA ORANG TUA YANG MEMILIKI ANAK RETARDASI MENTAL}

Di Amerika Serikat, setiap tahun dilahirkan sekitar 3000-5000 anak penyandang retardasi mental (Maulina, 2017). Hasil sensus penduduk Indonesia tahun 2009 menunjukan jumlah anak retardasi mental di Indonesia sebesar 22,07\% dari 439 ribu anak cacat yang tersebar di seluruh kota dan kabupaten di Indonesia (Asra, 2013).

Retardasi mental yang dialami anak tentunya sulit diterima oleh orang tua, ketika anaknya berbeda dengan anak-anak yang lain dan memiliki keterbatasan. Keadaan ini membuat orang tua kesulitan menerima keadaan anak, menghadapi permasalahanpermasalahan yang timbul, serta menghadapi tekanan dari masyarakat sebab anak dengan retardasi mental jarang diterima dan sering ditolak oleh masyarakat. Orang tua dengan anak retardasi mental menghadapi banyak tantangan. Tantangan yang dihadapi oleh orang tua berupa isolasi sosial, lingkungandan teman yang tidak dapat memahami keperluan anak dengan retardasi mental (Safitri \& Hapsari, 2013). Perasaan senang, bahagia dan bangga yang dirasakan oleh orang tua saat anak lahir menjadi perasaan marah, menolak, sedih, malu, merasa bersalah, cenderung mengasihani diri sendiri dan depresi.

Orang tua juga merasa tidak percaya diri, merasa tidak berdaya dan kehilangan harapanharapan yang relistik karena kehadiran anak yang tidak sesuai dengan yang harapan
(Maulina, 2017). Hal ini merupakan tantangan yang harus dihadapi oleh orang tua dan dapat menjadi beban sehingga menyebabkan stres pada orang tua (Fitriani \& Ambarini, 2013).

Orang tua dengan anak retardasi mental memiliki tingkat kecemasan yang tinggi dibandingkan dengan orang tua yang memiliki anak normal, sehingga tingkat stres orang tua dari anak retardasi mental juga lebih tinggi dibandingkan orang tua dengan anak yang normal (Ariesti \& Indah, 2017). Stres merupakan keseluruhan proses yang meliputi stimulasi, kejadian, peristiwa, respon, dan interprestasi individu yang menyebabkan timbulnya ketegangan di luar kemampuan seseorang untuk mengatasinya (Rice, 1992). Stres memiliki dua dampak, pertama stres secara fisik yaitu sistem kekebalan tubuh mengalami penurunan sehingga seseorang mudah terserang penyakit dan yang kedua secara psikis yaitu timbulnya perasaan negatif. Perasaan negatif ini akan menjadikan mereka mudah murung, kesepian, sedih, dendam, benci dan merasa tidak berguna. Pada tahap selanjutnya kondisi ini dapat memunculkan keputusasaan yang menjurus pada tindakan nekat bunuh diri (Alloy, Acocella dan Bootzin, 1996; Safaria, 2005).

Kondisi stres yang dialami ibu dapat menyebabkan ibu tidak dapat mengasuh anaknya dengan baik (Rahmawati, Machmuroch, \& Nugroho, 2013). Kondisi ini dapat diperbaiki dengan bantuan dukungan

Rada Tri Rosi Kurnia, Program Studi Pendidikan Dokter, Universitas Malahayati, Bandar Lampung. Email: radatrirosikurnia.97@gmail.com

Asri Mutiara Putri, Program Studi Psikologi, Universitas Malahayati, Bandar Lampung. Email: asri@malahayati.ac.id

Dita Fitriani, Program Studi Pendidikan Dokter, Universitas Malahayati, Bandar Lampung. 


\section{DUKUNGAN SOSIAL DAN TINGKAT STRES PADA ORANG TUA YANG MEMILIKI ANAK RETARDASI MENTAL}

sosial dari lingkungan. Dukungan sosial sendiri dapat berasal dari orang tua, pasangan, anggota keluarga, teman, komunitas dan masyarakat sekitar. Dukungan sosial meliputi pemberian semangat dan perhatian. Dukungan sosial dapat mencegah kecemasan, meningkatkan harga diri, mencegah gangguan psikologis dan mengurangi stres (Safitri \& Hapsari, 2013).

Berdasarkan hasil penelitian Purnomo \& Kristiana (2016), stres pengasuhan yang muncul pada istri yang memiliki anak retardasi mental dapat berkurang melalui strategi coping stress (usaha untuk menanggulangi stres) yang tepat. Sumber-sumber yang dapat berperan menjadi fasilitator sebagai coping stress salah satunya adalah strategi coping eksternal yaitu dukungan sosial. Dukungan sosial dapat bersumber dari anggota keluarga, khususnya pasangan, kerabat, teman dan keluarga. Berdasarkan penelitian yang dilakukan Safitri \& Hapsari (2013) terdapat pengaruh yang positif dari dukungan sosial keluarga terhadap resiliensi ibu yang memiliki anak retardasi mental. Ibu yang menerima dukungan sosial keluarga dengan baik memandang suatu situasi yang penuh tekanan dengan tenang, sebab ibu yang mendapatkan dukungan sosial keluarga akan berusaha mengubah respon terhadap sumber tekanan dan mencari seseorang untuk membantu meringankan beban yang ditanggung. Penyataan tersebut didukung dengan hasil penelitian Yasin \& Dzulkifli (2010) dimana dukungan sosial merupakan elemen yang membantu individu mengurangi pengalaman penuh stres dan mengatasinya.

Berdasarkan paparan di atas, penelitian ini akan mengkaji tentang hubungan dukungan sosial denga stress pada orang tua yang memiliki anak retardasi mental. Penelitian ini diharapkan dapat menyumbangkan informasi bagi perkembangan ilmu pengetahuan khususnya terkait stress pengasuhan orang tuan anak retardasi mental dan peran dukungan sosial dalam mengatasinya.

\section{METODE}

Penelitian ini merupakan penelitian jenis analitik kuantitatif dengan pendekatan Cross Sectional, yang dilakukan pada bulan Januari dan Februari 2019 di SLB se-Bandarlampung, provinsi Lampung, Indonesia. Sampel sebanyak 122 orang tua dari anak Retardasi Mental yang diambil dengan teknik acidental sampling. Pengambilan data dilakukan dengan menyebarkan kuesioner. Kuesioner yang digunakan yaitu skala dukungan sosial dan kuesioner Perceived Stress Scale 10 (PSS-10).

Rada Tri Rosi Kurnia, Program Studi Pendidikan Dokter, Universitas Malahayati, Bandar Lampung. Email: radatrirosikurnia.97@gmail.com

Asri Mutiara Putri, Program Studi Psikologi, Universitas Malahayati, Bandar Lampung. Email: asri@malahayati.ac.id

Dita Fitriani, Program Studi Pendidikan Dokter, Universitas Malahayati, Bandar Lampung. 
DUKUNGAN SOSIAL DAN TINGKAT STRES PADA ORANG TUA YANG MEMILIKI ANAK RETARDASI MENTAL

\section{HASIL}

Tabel 1

Distribusi Frekuensi Karakteristik Orang Tua Berdasarkan Dukungan Sosial

\begin{tabular}{lll}
\hline Dukungan Sosial & Jumlah & Persentase \\
\hline Tinggi & 108 & $88.5 \%$ \\
Sedang & 11 & $9.0 \%$ \\
Rendah & 3 & $2.5 \%$ \\
\hline Total & 122 & $100 \%$ \\
\hline
\end{tabular}

Berdasarkan tabel diatas diketahui bahwa sebagian besar Orang Tua mendapatkan dukungan sosial tinggi yaitu sebanyak 108 orang dengan persentase $(88,5 \%)$.

\section{Tabel 2}

Distribusi Frekuensi Orang Tua Berdasarkan Tingkat Stres

\begin{tabular}{lll}
\hline Tingkat Stres & Jumlah & Presentase (\%) \\
\hline Ringan & 114 & 93.4 \\
\hline Sedang & 6 & 4.9 \\
\hline Berat & 2 & 1.6 \\
\hline Total & $\mathbf{1 2 2}$ & $\mathbf{1 0 0}$ \\
\hline
\end{tabular}

Berdasarkan tabel diatas diketahui bahwa sebagian besar orang tua memiliki tingkat stres ringan yaitu sebanyak 114 orang dengan persentase $(93,4 \%)$.

\section{Tabel 3}

Hubungan Dukungan Sosial dengan Tingkat Stres Orang Tua dari Anak Retardasi Mental

\begin{tabular}{ll}
\hline Variabel & Stress \\
\hline Dukungan Sosial & $-.989^{* * *}$ \\
\hline$n=122$ & \\
$* * *$ & $p<.001$.
\end{tabular}

Berdasarkan tabel di atas didapatkan nilai signifikan $P<.001$ dengan $r=-.989$ artinya hipotesis penelitian terbukti sehingga dapat disimpulkan terdapat hubungan yang signifikan antara dukungan sosial dengan tingkat stres orang tua dari anak retardasi mental. Nilai $r$ yang bertanda negatif menunjukkan adanya arah hubungan yang berlawanan, artinya semakin tinggi dukungan sosial yang didapat maka semakin rendah tingkat stres yang dialami orang tua dari anak.

Rada Tri Rosi Kurnia, Program Studi Pendidikan Dokter, Universitas Malahayati, Bandar Lampung. Email: radatrirosikurnia.97@gmail.com

Asri Mutiara Putri, Program Studi Psikologi, Universitas Malahayati, Bandar Lampung. Email: asri@malahayati.ac.id

Dita Fitriani, Program Studi Pendidikan Dokter, Universitas Malahayati, Bandar Lampung. 


\section{DUKUNGAN SOSIAL DAN TINGKAT STRES PADA ORANG TUA YANG MEMILIKI ANAK RETARDASI MENTAL}

\section{DISKUSI}

Hasil penelitian ini menunjukkan ada hubungan yang signifikan antara dukungan sosial dengan stress yang dialami orang tua anak retardasi mental. Hasil penelitian ini sesuai dengan temuan Safitri \& Hapsari (2013) bahwa orang tua yang menerima dukungan sosial keluarga dengan baik akan memandang situasi yang penuh tekanan dengan tenang, sebab ibu yang mendapatkan dukungan soaial dari keluarga akan mengubah respon terhadap sumber tekanan dan berusaha mencari seseorang untuk membantu meringankan beban yang ditanggung.

Beberapa penelitian yang mendukung hasil penelitian ini diantaranya penelitian yang dilakukan oleh Puspitasari (2017) pada ibu (orang tua) yang memiliki anak retardasi mental di SLB Negeri Semarang menemukan bahwa terdapat hubungan yang signifikan antara dukungan sosial dengan penerimaan ibu yang memiliki anak retardasi mental. Dalam penelitian tersebut dijelaskan bahwa orang tua yang lebih sering mendapatkan dukungan dari lingkungannya cenderung bersikap lebih menerima anak-anak mereka yang terhambat secara fisik maupun mental. Hasil penelitian ini juga sejalan dengan penelitian yang dilakukan oleh Yuliana \& Hartati (2017) bahwa ibu yang memiliki anak dengan retardasi mental yang mengalami stres pengasuhan berkurang dengan adanya dukungan sosial yang berasal dari keluarga.

Dampak dari keterbatasan anak dengan retardasi mental mengakibatkan ketergantungan anak terhadap orang tua sehingga orang tua akan lebih merasakan beban dan kelelahan dalam proses pengasuhan anak dan lebih rentan mengalami stres psikologis (Fitriani \& Ambarini, 2013). Stres yang dialami orang tua disebabkan karena kelelahan atau beban dalam merawat anak retardasi mental yang membutuhkan waktu tambahan dalam merawat anak retardasi mental, tingkat kesabaran yang tinggi, tanggung jawab yang tidak terbatas, rasa malu yang dialami keluarga dengan kondisi anaknya dan juga efek stigmatisasi dari masyarakat yang akan berdampak terhadap kehidupan orang tua (Pawino, et al., 2016).

Ketika seseorang didera suatu permasalahan maka diperlukan berbagai sumber coping. Sumber coping dapat berasal dari diri sendiri (coping personal) atau berasal dari luar yang lebih dikenal sebagai dukungan sosial (social support). Dukungan sosial atau pertolongan dari orang lain merupakan salah satu hal yang sangat penting ketika individu mengalami suatu permasalahan. Terdapat berbagai macam jenis dukungan sosial, baik berupa bantuan materi (uang, barang, atau pelayanan/jasa), dukungan emosional hingga bantuan berupa informasi-informasi yang relevan bagi pemecahan masalah. Dukungan

Rada Tri Rosi Kurnia, Program Studi Pendidikan Dokter, Universitas Malahayati, Bandar Lampung. Email: radatrirosikurnia.97@gmail.com

Asri Mutiara Putri, Program Studi Psikologi, Universitas Malahayati, Bandar Lampung. Email: asri@malahayati.ac.id

Dita Fitriani, Program Studi Pendidikan Dokter, Universitas Malahayati, Bandar Lampung. 


\section{DUKUNGAN SOSIAL DAN TINGKAT STRES PADA ORANG TUA YANG MEMILIKI ANAK RETARDASI MENTAL}

sosial dapat bersumber dari pasangan, anggota

keluarga, teman, rekan kerja, tetangga, atau

perkumpulan yang diikuti (Hidayati, 2011).

\section{SIMPULAN DAN SARAN}

Berdasarkan hasil penelitian, dapat disimpulkan terdapat hubungan yang signifikan antara dukungan sosial dengan tingkat stres orang tua yang memiliki anak retardasi mental. Hasil penelitian ini memberikan implikasi terhadap berbagai pihak seperti keluarga dari anak retardasi mental serta masyarakat umum untuk lebih menerima kondisi dan keterbatasan yang dimiliki anak retardasi mental sehingga bisa memberikan lebih banyak dukungan sosial kepada orang tua untuk mengurangi stress yang diamali dalam mengasuh anak retardasi mental. Untuk penelitian selanjutnya diharapkan dapat melakukan pengembangan penelitian pada faktor lain yang berhubungan dengan stres yang dialami orang tua dari anak retardasi mental, seperti karakteristik orang tua dan masalah perilaku anak. Selain itu, akan lebih baik lagi jika melakukan intervensi untuk mengurangi tingkat stres orang tua dengan memanfaatkan faktor dukungan sosial.

\section{DAFTAR PUSTAKA}

Alloy, L. B., Riskind, J. H., \& Manos, M. J. (2005). Abnormal psychology: Current perspectives (Vol. 278). McGraw Hill.

Ariesti, B. F., Indah A., 2017. Tingkat Kecemasan lbu dengan Anak Tuna
Grahita Berdasarkan Hamilton Anxiety Rating Scale (HAM-A) di Sekolah Luar Biasa C dan C1 Negeri Kota Denpasar Tahun 2014. E-Jurnal Medika, 6(3), pp. 1-6.

Asra, Y. K., 2013. Efektivitas Psikoedukasi pada Orang tua Dalam Meningkatan Pengetahuan. Jurnal Psikologi, 9(1), pp. 64-72.

Fitriani, A., Ambarini, T. K., 2013. Hubungan antara Hardiness dengan Tingkat Stres Pengasuhan pada lbu dengan Anak Autis. Jurnal Psikologi Klinis dan Kesehatan Mental, 2(1), pp. 34-40.

Hidayati, N. (2011). Dukungan sosial bagi keluarga anak berkebutuhan khusus. INSAN, 13(1), 12-20.

Kusumastuti, A. N., 2014. Stres lbu Tunggal Yang Memiliki Anak Autis. Jurnal Psikologi, 2(7), pp. 54-60.

Maulina, B., 2017. Tingkat Stres Ibu yang Memiliki Anak Penyandang Retradasi Mental. Wahana Inovasi, 6(2), pp. 120124.

Nurhidayati, N., Nurdibyanandaru, D., 2014. Hubungan antara Dukungan Sosial Keluarga dengan Self Esteem pada Penyalahguna Narkoba yang Direhabilitasi. Jurnal Psikologi Klinis dan Kesehatan Mental, 3(03), pp.52-29.

Purnomo, J. C., Kristiana, I. F., 2016. Hubungan Antara Dukungan Sosial Suami dengan Stres Pengasuhan Istri Yang Memiliki Anak Retardasi Mental Ringan dan Sedang. Jurnal Empati, 5(3), pp. 507512.

Puspitasari, E., 2017. Hubungan dukungan sosial dengan penerimaan ibu dengan

Rada Tri Rosi Kurnia, Program Studi Pendidikan Dokter, Universitas Malahayati, Bandar Lampung. Email: radatrirosikurnia.97@gmail.com

Asri Mutiara Putri, Program Studi Psikologi, Universitas Malahayati, Bandar Lampung. Email: asri@malahayati.ac.id

Dita Fitriani, Program Studi Pendidikan Dokter, Universitas Malahayati, Bandar Lampung. 
DUKUNGAN SOSIAL DAN TINGKAT STRES PADA ORANG TUA YANG MEMILIKI ANAK RETARDASI MENTAL

anak retardasi menta di SLB N Semarang.

Rahmawati, N. A., Machmuroch \& Nugroho, A. A., 2013. Hubungan antara Penerimaan Diri dan Dukungan Sosial dengan Stres pada Ibu yang Memiliki Anak Autis di SLB Autis di Surakarta. Jurnal IImiah Psikologi Candrajiwa, 2(2), pp. 16-29.

Rice, P. L. (1999). Stress and Health. California: Brooks.

Sadock, B. J., Sadock, V. A., 2010. Kaplan dan Sadock Buku Ajar Psikiatri Klinis. 2 penyunt. Jakarta: EGC.

Safaria, T. (2005). Autisme: pemahaman baru untuk hidup bermakna bagi orang tua. Graha IImu.

Safitri, K., Hapsari, I. I., 2013. Dukungan Sosial Keluarga Terhadap Resiliensi pada Ibu dengan Anak Retardasi Mental. Jurnal Penelitian dan Pengukuran Psikologi, 2(2), pp. 76-79.

Santrock, J. W., 2007. Perkembangan Anak. 2 penyunt. Jakarta: Erlangga.

Sarafino, E. and Smith, T., 2011. Health psychology biopsychosocial interaction. United State Of Amerika: John Wlley \& Sons.

Suciani, D., Safitri, S., 2014. Hubungan Dukungan Sosial Dengan Motivasi Belajar Pada Mahasiswa Universitas Esa Unggul. Jurnal Esa Unggul, 12(02).

Utami, R.D., 2016. Pengaruh Humor Terhadap Penurunan Tingkat Stres Mahasiswa Psikologi Yang Mengerjakan Skripsi Di Universitas Negeri Semarang (Doctoral dissertation, Universitas Negeri Semarang).

\author{
Yasin, A.S. and Dzulkifli, M.A., 2010. The \\ Relationship Between Social Support \\ And Psychological Problems Among \\ Students. International Journal of \\ Business and Social Science, 1(3). \\ Yuliana, M. S., Hartati, E., 2017. Hubungan \\ Antara Dukungan Sosial Keluarga Dan \\ Self Efficacy Dengan Stres Pengasuhan \\ Pada Ibu Yang Memiliki Anak Retardasi \\ Mental Di Slb Negeri Semarang (Doctoral \\ Dissertation, Faculty Of Medicine).
}

Rada Tri Rosi Kurnia, Program Studi Pendidikan Dokter, Universitas Malahayati, Bandar Lampung. Email: radatrirosikurnia.97@gmail.com

Asri Mutiara Putri, Program Studi Psikologi, Universitas Malahayati, Bandar Lampung. Email: asri@malahayati.ac.id

Dita Fitriani, Program Studi Pendidikan Dokter, Universitas Malahayati, Bandar Lampung. 